\title{
INTERNATIONAL COMMISSION ON ZOOLOGICAL NOMENCLATURE
}

The required six months' notice is given of the possible use of plenary powers by the International Commission on Zoological Nomenclature in connexion with the following names listed by case number (see Bull. zool. Nom. 34, part 1, 1 July 1977).

Case No.

2135 Bonelli, 1811, 'Tabula Synoptica': proposal to rule an available work. 1578 Ophidium parrii Ross, 1826 (Pisces): application for suppression.

Comments should be sent in duplicate (if possible within six months of the date of publication of this notice), citing case number to:

R. V. Melville,

The Secretary,

International Commission on Zoological Nomenclature,

c/o British Museum (Natural History),

Cromwell Road,

London SW7 5BD,

England.

Those received early enough will be published in the Bulletin of Zoological Nomenclature.

The following Opinions have been published recently by the International Commission on Zoological Nomenclature, c/o British Museum (Natural History), Cromwell Road, London SW 7 5BD, England (see Bulletin of Zoological Nomenclature, volume 34, part 1).

1082 (p. 27) Use of the plenary powers to give the specific name kleinebergi, Eretmophorus, Giglioli, 1889 precedence over the specific name benoit, Pharopteryx, Rüppell, 1852 (Pisces).

1086 (p. 37) Pseudanisakis tricupola Gibson, 1973 designated under the plenary powers as type-species of Pseudanisakis Layman \& Borovkova, 1926 (Nematoda).

The Commission cannot supply separates of Opinions. 


\section{INTERNATIONAL COMMISSION OF ZOOLOGICAL NOMENCLATURE}

The required six months' notice is given of the possible use of plenary powers by the International Commission on Zoological Nomenclature in connexion with the following names listed by case number: (see Bull. zool. Nom. 34, part 2, 31 August 1977).

Case No.

1877 Galaxias platei Steindachner, 1898 (Pisces): proposal to give precedence over Galaxias delfini Philippi, 1895.

2183 Sebastichthys hubbsi Matsubara, 1937: proposed designation of type-species of the subgenus Sebastocles (SCORPAENIDAE, Pisces).

2190 Acidaspis coronata Salter, 1853 (Trilobita): proposed conservation under the plenary powers.

2192 Haliplanella Hand, 1955 (Anthozoa): proposed conservation in place of Haliplanella Treadwell, 1943 (Polychaeta).

2202 Pectinaria Lamarck, 1818, Nereis cylindraria belgica Pallas, 1766, and Lagis koreni Malmgren, 1866 (Polychaeta): proposed conservation.

2207 Athelges Gerstaecker, 1862 (Crustacea, Isopoda): proposed conservation.

Comments should be sent in duplicate (if possible within six months of the date of publication of this notice), citing case number to:

R. V. Melville,

The Secretary,

International Commission on Zoological Nomenclature,

c/o British Museum (Natural History),

Cromwell Road,

London $\mathrm{SW}_{7} 5 \mathrm{BD}$,

England.

Those received early enough will be published in the Bulletin of Zoological Nomenclature. 